研究

\title{
傾斜構造を有する炭化ケイ素シャンクのダイヤモンド精密切削工具の開発
}

\author{
李敬鋒的，西尾 典幸沏2 \\ 川崎亮的，渡辺・龍三心1

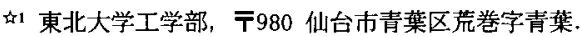

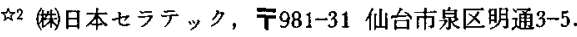

\section{Development of Diamond Tools for Superprecision Machining with Compositionally Graded Layers from Silicon Carbide Shank to Diamond Chip}

\author{
Jing-Feng Li ${ }^{\Uparrow 1}$, Noriyuki Nishio ${ }^{i 2}$

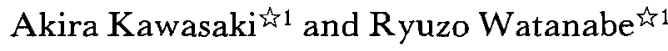 \\ t1 Faculty of Engineering, Tohoku University, Aramaki-aza-aoba, Sendai 980. \\ t2 $^{2}$ Nihon Ceratec Company Ltd., 3-5 Akedori Izumi-ku, Sendai 981-31.
}

Received February 10, 1994

\begin{abstract}
Diamond cutting tools are getting increasing uses for superprecision machining. For conventional diamond tools, a vibration known as slight waviness is generated to deteriorate the machining accuracy because of the low stiffness of silver solder containing active metals used to join a diamond chip onto a metallic alloy shank. In order to overcome this problem, a diamond tool with silicon carbide shank by reaction sintering was developed. Numerical calculation by the finite element method (FEM) was carried out to clarify the thermal residual stresses between the diamond chip and silicon carbide shank with and without compositionally graded joining layers. The FEM calculation clearly showed that thermal stress between the diamond chip and silicon carbide shank was greatly reduced by inserting the compositionally graded layers. The fabrication process and performance of the developed diamond tool were also described.
\end{abstract}

\section{1 緒 言}

光学機器やコンピュータ機器においては、コンタク トレンスやコンピュータのハードディスク基板, レー ザプリンタのボリコンミラーなど超精密な加工精度が 要求される部品が多い。それらのハイテク部品はアル ミニウム合金やブラスチックなどの軟質素材から作ら れており，その切削加工にタイヤモンド工具，特に単 結晶ダイヤモンド(いわゆる Single Point Diamond)工 具がよく使用されている゙，従来の工具では，超硬合金 のシャンク（柄の部分）にダイモンド単結晶がろう 付け加工されている。しかし，ろう付け部分の解性が
不十分なため，加工時に”びびり”といわれる振動が 発生し，加工精度が低下するという問題がよく起き ろ.したがって，ろう付け層を介しない，シャンクと タイヤモンドチッブとの一体化接合が望まれている。

そこで, シャンク材質を炭化ヶイ素に变えることに より，反応焼結により炭化ケイ素シャンクを形成する と同時にシャンクとタイヤモンドチッブとを一体成形 する方法が考案された22,3\}. しかし，Fig.1 に示すよう に，炭化ケイ素シャンクの先端にタイヤモンドチップ を直接接合した場合，ダイヤモンドと炭化ケイ素との 間には良い接合界面が形成されたものの，タイヤモン 


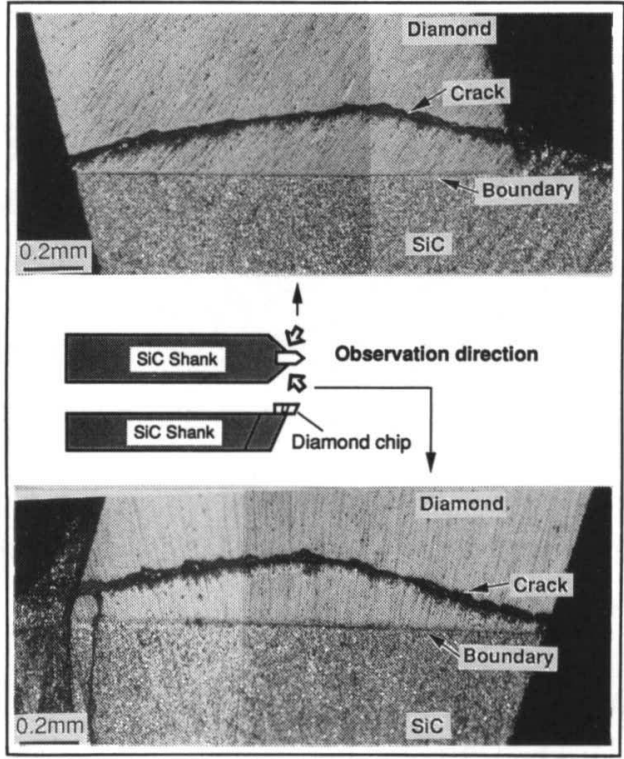

Fig. 1 Typical crack observed in the diamond chip directly bonded onto silicon carbide shank.

ドチッブ側にクラックが生じた，後述のように，この クラックの発生は炭化ケイ素とダイヤモンドとの熱物 性のミスマッチに起因する熱応力によるものと推測さ れる，この熱応力を楥和するためには，炭化ケイ素 シャンク側のダイヤモンドチップへの接合部分におい て,ダイヤンドと炭化ケイ素の組成比を変化させる 傾斜組成層を導入するのが有効であると考えられる。

本報告では，有限要素法によるダイヤモンドと炭化 ケイ素との間に生じる勗応力の解析と, それに基づく 傾斜構造を有するダイヤモンド/炭化ケイ素系精密切 削工具の作製プロセスについて述べる。

\section{2 試料および実験方法}

2-1 炭化ケイ素/タイヤモンド（SiC/Dia）複合体 （無傾斜材）の作製と物性值測定

炭化ケイ素粉末にタイヤモンド粉末を0 80vol\%の 割合で混合し，さらに炭素系成形郕を添加した混合粉 を金型タイスにより弾性率測定用の角棒状試料（長さ $35 \mathrm{~mm} \times$ 幅 $4 \mathrm{~mm} \times$ 高さ $3 \mathrm{~mm}$ ) と熟膨張係数测定用の円 柱状試料（直径 $10 \mathrm{~mm} \times$ 高さ $10 \mathrm{~mm}$ ) に仮成形した. 次 に, 炭素系成形剤の炭化処理を行いカーボンと炭化ケ イ素粒子（1次粒子）からなる多孔質のプリフォームを 得た。プリフォームに溶融シリコンを溶浸すると， カーボンとシリコンが反応して 2 次炭化ケイ素結晶が
生成される4ことにより緻密な炭化ケイ素/タイヤ モンド複合体が得られる.

得られた試料についてヤング率，ポアソン比および 熟膨張係数を測定した。ヤング率とポアソン比はひず みゲージを併用した 4 点曲げ試験法により，熱膨張係 数はディラトメータによる室温から $900^{\circ} \mathrm{C}$ ま゙の平均 値として求めた.

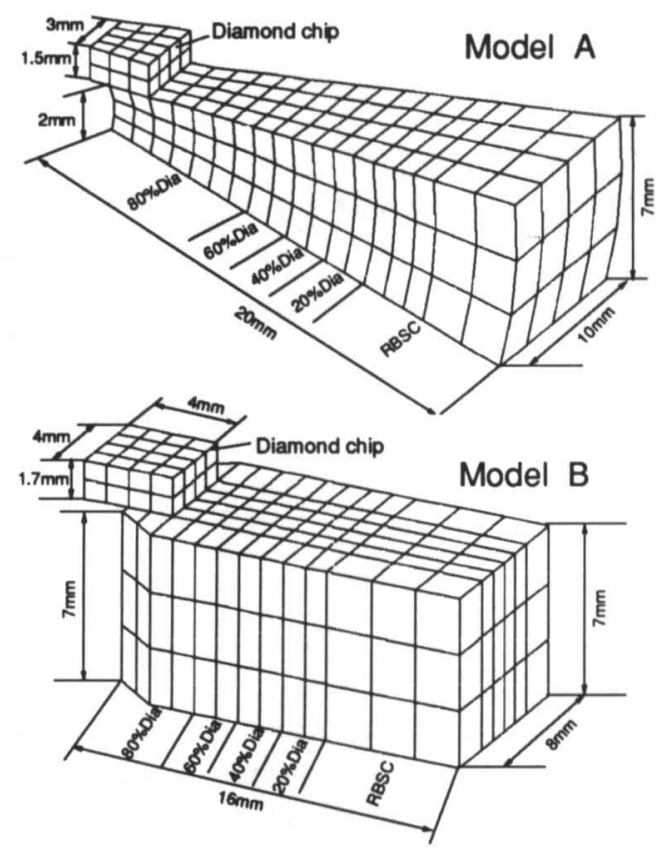

Fig. 2 3-D models for FEM calculation of thermal residual stress in the diamond tools. Model (A) for machining contact-lenses, model (B) for machining polygon mirrors.

\section{2-2 有限要素法による熟応力計算}

製造温度 $\left(1400^{\circ} \mathrm{C}\right)$ から室温まで冷却する過程に おいて生じる熱応力を計算する. 計算は汎用有限要素 解析法であるMARC-SYSTEMにより，またFig. 2 に 示すように工具の先端接合部分と同じ形状を有する 3 次元モデルを用いた，計算温度範囲では，本系材料の 塑性変形は考えられないので, 計算には弾性変形のみ 考慮した。 また，傾斜化接合の場合は，図中に示した ような組成分布を付与した.

\section{3 実験結果および考察}

Fig. 3 に炭化ケイ素単体拧よび炭化ケイ素/タイヤ モンド椱合体の破面のS E M写真を示す。いずれも相 対密度が95\%以上の緻密な焼結体である. 写真の中に 


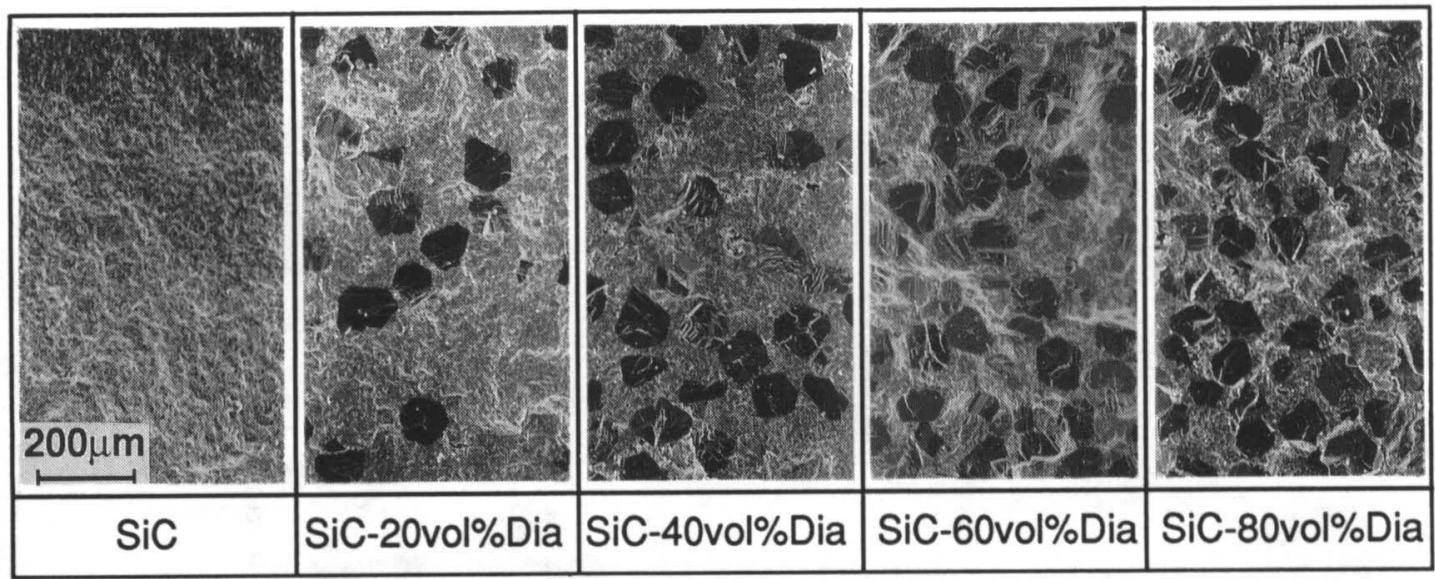

Fig. 3 SEM micrographs of the fractured surfaces of reaction sintered $\mathrm{SiC}$ and $\mathrm{SiC} / \mathrm{Diamond}$ composites.

Table 1 Properties of reaction sintered $\mathrm{SiC}$ and $\mathrm{SiC} / \mathrm{Dia}-$ mond composites

\begin{tabular}{c|c|c|c}
\hline \multirow{2}{*}{ Materials } & \multicolumn{3}{|c}{ Properties } \\
\cline { 2 - 4 } & $\mathrm{E}(\mathrm{GPa})$ & $v$ & $\alpha\left(\mathrm{K}^{-1}\right)$ \\
\hline $\mathrm{SiC}$ & 361 & 0.171 & $5.42 \times 10^{-6}$ \\
\hline $\mathrm{SiC}-20 \%$ Dia & 411 & 0.158 & $4.87 \times 10^{-6}$ \\
\hline $\mathrm{SiC}-40 \%$ Dia & 426 & 0.155 & $4.17 \times 10^{-6}$ \\
\hline SiC-60\%Dia & 484 & 0.155 & $3.85 \times 10^{-6}$ \\
\hline SiC-80\%Dia & 560 & 0.129 & $3.75 \times 10^{-6}$ \\
\hline Diamond & 1054 & 0.1 & $3.70 \times 10^{-6}$ \\
\hline
\end{tabular}

(E: Young's modulus, v: poisson's ratio, $\alpha$ : coefficient of thermal expansion)

黒く見える粒子は平均粒径が約 $100 \mu \mathrm{m}$ のダイヤモンド 結晶粒であるが, その他にFig. 3 の写真では判別できな い平均粒径約 $2 \mu \mathrm{m}$ のダイヤモンド粒子も含まれてい る.

Table 1 に実測した炭化ケイ素単体および炭化ケイ素 ノダイヤモンド複合体のヤング率，ポアンン比および熱 膨張係数を示す。ダイヤモンドについての值は参考文 献5から引用したものである。 ヤング率はダイヤモンド に比べて炭化ケイ素の方が小さいが, 熱膨張係数は炭化 ケイ素の方が大きい. 複合体は組成に応じた值を示す. 以 下の熹応力計算にはTable 1 に示した物性値を用いた。

Fig. 4 にFig. 2 に示した 2 種の計算モデルについて得 られた各主応力の最大応力値を示す、いずれのモデルに おいても, 直接接合の場合は最大の引張り垂直応力と最 大のせん断応力が約 $400 \mathrm{MPa}$ に達する. 傾斜化接合を行 うことにより，各成分応力はそれぞれ約 10～80\%に低 減することがわかる.
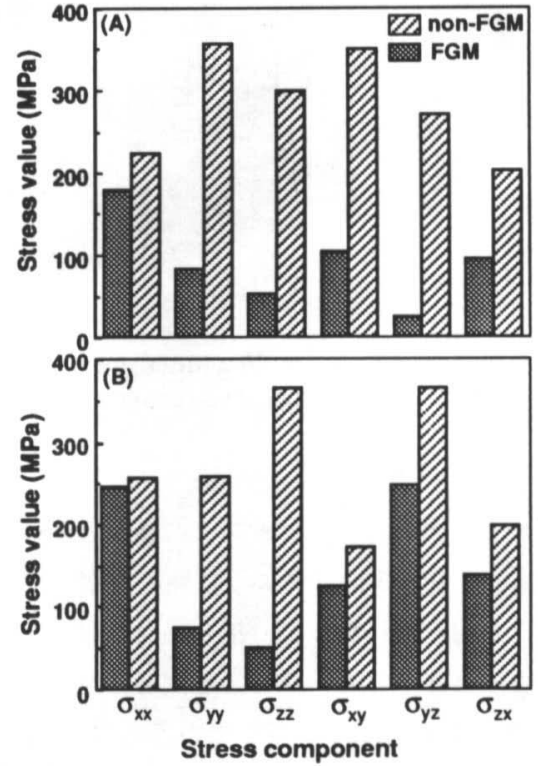

Fig.4 Comparison of thermal residual stress in the diamond tools with and without FGM joining layers. Model (A) for contact lens, model (B) for polygon mirror.

Fig. 5 にダイヤモンドチップと炭化ケイ素シャンク との無傾斜接合について得られたフォン・ミッセスの 相当応力分布を示す. 2 種のモデルにおいてほほ同様 な熱応力分布が得られた. 応力は接合界面に集中して おり，その最大値は約 $1000 \mathrm{MPa}$ 達することが示さ れている。また応力成分を解析した結果, 垂直応力は ダイヤモンドチップ側で, せん断応力は接合界面近傍 で最大值を示すことが分かっており，このことにより Fig.1に示したようなクラックが生じたと考えられ る. 


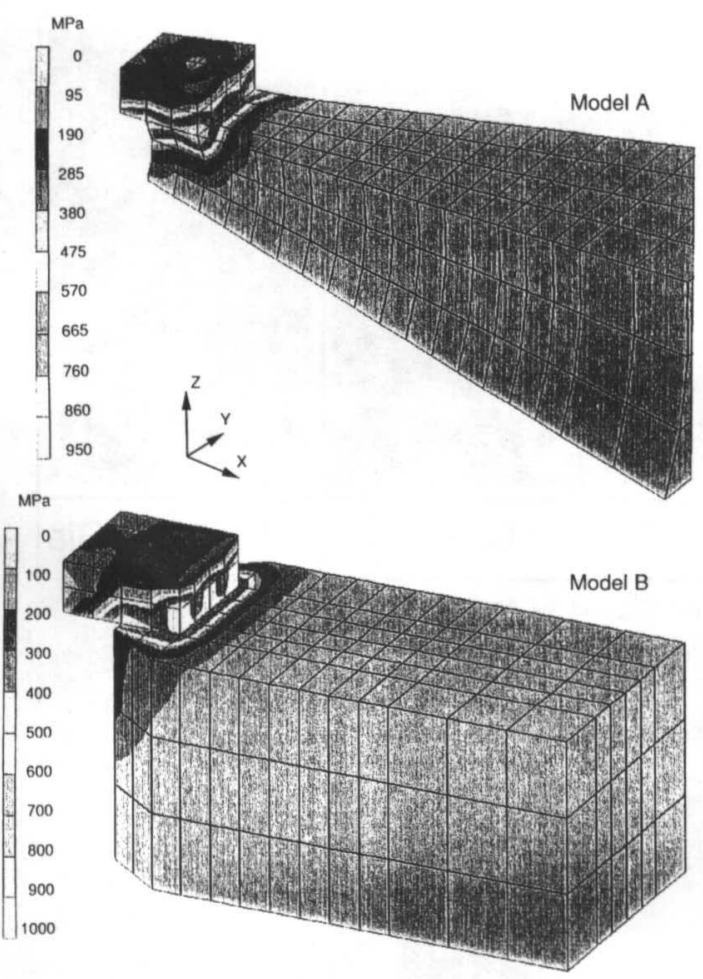

Fig.5 Distribution of equivalent Von Mises stress in the tools with the diamond chip directly bonded onto the SiC shank.

ダイヤモンドチップとシャンクの接合近傍に傾斜層を 導入すると, Fig. 6 に示すように熱応力が大幅に緩和さ れたことが明らかになった．接合界面における応力集中 がなくなったばかりではなく, 最大応力値も無傾斜接合 の約 $1 / 3$ になった．この時点での応力集中は $\mathrm{SiC}-20 \%$ DiaとSiC単体の間に見られるが,さらに必要に応じて その間により細かい傾斜組成層を入れると，熱応力をよ り低減できると考えられる。

\section{4 傾斜構造を有する工具の作製}

Fig. 7 に傾斜構造を有するダイヤモンド工具の作製プ ロセスの模式図を示すまず，2-1に述べた無傾斜材の 作製プロセスと同様に，配合比の異なる炭化ケイ素粉末 とダイヤモンド粉末,および炭素系成形剂の混合体から 板状の仮成形体を作製する，次に，工具の形状を有する 金型ダイスの先端部分にその仮成形体を積層配置した状 態で加圧成形してシャンクの仮成形体を作る。その仮成 形体について崖化処理を行い, 先端部分でダイヤモンド 含有量を変化させたシャンクのプリフォームを作製す

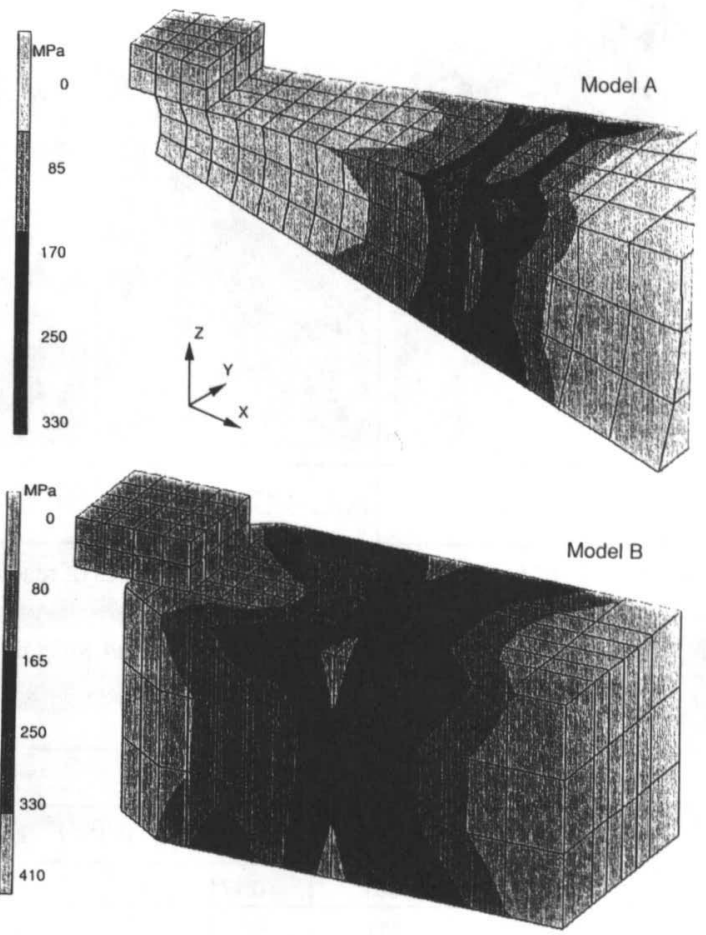

Fig.6 Distribution of equivalent Von Mises stress in the tools with FGM joining layers from the $\mathrm{SiC}$ shank to the diamond chip.

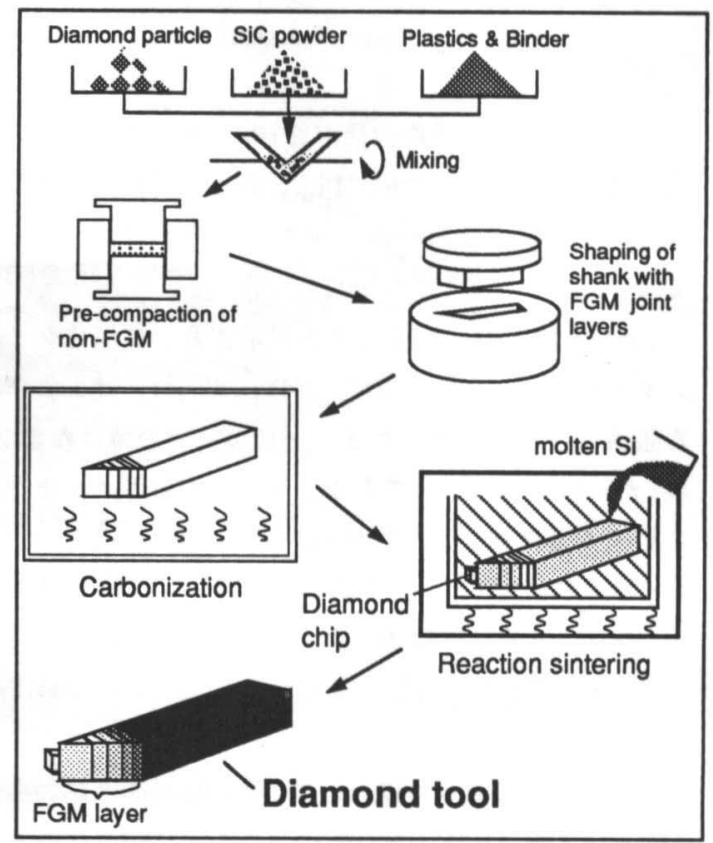

Fig.7 Schematic drawing of fabrication process of diamond tools with FGM joining layers from the SiC shank to the diamond chip. 


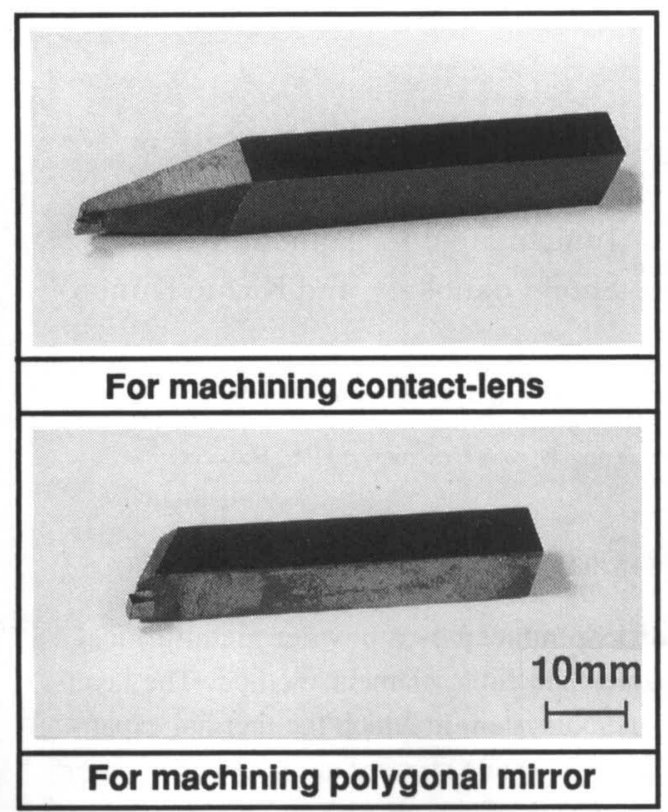

Fig.8 Macro views of the developed diamond tools with FGM joining layers from the $\mathrm{SiC}$ shank to the diamond chip.

ろ. 最後にシャンクの先端にダイヤモンドチップを配置 しておいて, シリコンを溶浸することによりダイヤモン ドチッブがシャンクに強固に付いた工具が得られる.

Fig. 8 に作製したタイヤモンド工具の全体写真を示す. 従来のろう付けタイプのタイヤモンド工具に比べて, 開 発したタイヤモンド工具は加工精度と寿命はそれぞれ 5 〜6倍および1.3倍向上したことが明らかになった．

傾斜化を施した工具におけるダイヤモンドチップと炭 化ケイ素シャンクの接合はタイヤモンドとSiC 80vol\%Dia複合体との結合によるものである. Fig. 9 に 組織観察の結果を基にした結合の模式図を示す.シャン クの溶浸過程では局部的にタイヤモンドチップ表面とシ リコンが反応して厚さ約 $1 \sim 10 \mu \mathrm{m}$ の反応層を形成す ろ. その反応層は結晶構造が炭化ケイ素に近く, 結合層 の役割を果たしていると推測される.

\section{5 まとめ}

炭化ケイ素七ラミックスをタイヤモンド切削工具の シャンク材として用いると, 反応焼結法によりシャンク 形成と同時に, シャンクとタイヤモンドチッブ間にろう

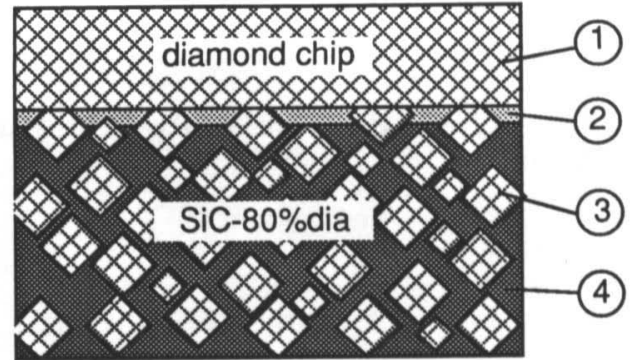

Fig.9 Schematic drawing of bonding structure in the diamond tool with FGM joiningl layers.

(1) diamond chip, (2) bonding phase,

(3) diamond particle,(4)reaction sintered $\mathrm{SiC}$.

材を介さない一体化接合の可能となる利点がある.し かし, 炭化ケイ素とダイヤモンドは熱膨張係数とヤン グ率が大きく異なるため, 直接接合では熱応力による クラックが生じ無欠陥の工具は得られていない。そこ て, タイヤモンドチップと炭化ケイ素シャンクとの接 合近傍にダイヤモンド粒子の含有量を段階状に変化さ せた傾斜組成層を導入することにより熟応力を大幅に 低隇することができ, 高性能のダイヤモンド工具が得 られる.

以上の結果について, 傾斜層導入の有無に分けて有 限要素法により熱応力の数值計算を行い, 傾斜化によ る繁応力の緩和効果を明らかにした。

謝辞

本開発工具の性能評価試験は株式会社東京タイヤモ ンド工具製作所高橋洋一, 小板橋康浩両氏によりな されたものである. 記して感謝申し上げる.

\section{文献}

1)田中克敏："ダイヤモンドッール", 日経技術図書, (1987), 764.

2) 西尾典幸, 鈴木 隆, 林 睦夫 : 特開平3-149107.

3) 西尾典幸 : 特願平3-141478.

4) 阿部 弘, 川合 実, 菅野隆志, 鈴木恵一朗 : " エン シニアリングセラミックス”，技報堂，（1985）, 102.

5) 小泉 聡, 犬塚直夫：エレクトロニク・セラミック ス, 23(117), (1992),11. 